\title{
Vaqueiros e fazendeiros na comarca de Geremoabo-Bahia no final dos oitocentos: trabalho, dominação e resistência
}

Joana Medrado**

\begin{abstract}
Resumo: Este artigo aborda as relações de trabalho entre vaqueiros e fazendeiros no Nordeste baiano por meio dos processos criminais envolvendo furto de animais na Comarca de Geremoabo entre 1880 e 1900 . Além desse tipo de processo ser uma janela privilegiada de análise da atuação dos personagens principais dessa história (vaqueiros e fazendeiros), ali estavam em jogo temas que nos interessam particularmente: concepções de poder, posse e propriedade. Nesses processos, desvelavam-se também outras faces dos atributos comumente associados aos vaqueiros, reiterados na literatura e na sociologia: fidelidade, diligência, honra da palavra, liberdade e autonomia. Por essas veredas, perscruta-se como esses valores eram tanto mecanismo de dominação acionados pelos fazendeiros quanto estratégias de resistência sabidamente manipuladas em favor dos subalternos.
\end{abstract}

Palavras-Chave: Pecuária - Brasil; Relações de trabalho; Cultura política.

Abstract: This article focuses on working relationship between landowners and highly-skilled cowmen (vaqueiros) in northeastern Bahia (Geremoabo) through trial records concerning the stealing of animals during the last two decades of the nineteenth century. Beside the fact this prosecutions are a strong documentation of our protagonist's life, they contain themes of special interest as well, such as power understanding, possession and property. These prosecutions disclose other points commonly attributed to the cowboys and reinforced in the sociology and literature: loyalty, diligence, word honor, freedom, and autonomy. By this ways we can knowledge how this values were used such as domination mechanisms by the farmers, such as resistance strategies wisely used by the subordinates.

Keywords: Cattle breeding-Brazil; Working relationship; Political culture.

Pensar política na virada do século XIX para o XX, em um contexto de instalação do estado republicano e de fortalecimento dos poderes locais, não pode prescindir de um olhar sobre os grupos subalternos que instabilizavam as intenções de dominação e matizavam as relações de poder. Este artigo vai abordar as relações entre fazendeiros e vaqueiros na Comarca de Geremoabo, Bahia, na tentativa de perceber aspectos da cultura política sertaneja a partir das relações de trabalho, dominação e resistência travadas entre esses

\footnotetext{
* Esta pesquisa foi realizada durante meu mestrado em história na Universidade Estadual de Campinas, entre 2006 e 2008 e foi financiada pela Fundação de Amparo à Pesquisa do Estado de São Paulo - FAPESP. Para uma visão mais aprofundada das ideias desenvolvidas neste artigo, ver minha dissertação: MEDRADO, Joana. "Terra, laço e moirão": relações de trabalho e cultura política na pecuária. Dissertação (Mestrado em História Social da Cultura). Campinas: UNICAMP/IFCH, 2008. E o livro que se encontra no prelo sob o título Terra de Vaqueiros: Relações de trabalho e cultura política no sertão da Bahia, 1880-1900, a ser lançado em 2013 pela Editora da Unicamp - Coleção Várias Histórias.

${ }^{* *}$ Doutoranda em História - Universidade Federal Fluminense.
} 
personagens. Antes, no entanto, caberão algumas palavras sobre essa comarca, seus personagens e sobre o contexto do final do Oitocentos.

Geremoabo era uma antiga e tradicional região de pecuária localizada no extremo Nordeste baiano. ${ }^{1}$ Essa região havia sido parte dos domínios dos Garcia d'Ávila, a poderosa Casa da Torre, no período colonial. A retração dos Ávila, já em meados do século XVIII, esteve associada ao antilusitanismo que se intensificou no período da independência política do Brasil e ensejou doações, vendas e abandono das terras. Foi nesse processo que a família Dantas tornou-se importante proprietária na região, comprando terras dos Ávila, anexandoas a outros territórios, consolidando a criação de gado e estabelecendo forte vínculo com a política local. De certo modo, pode-se afirmar que a família Dantas, da qual fazia parte Cicero Dantas Martins, o poderoso barão de Geremoabo, substituiu os Ávila no Nordeste baiano oitocentista. Filhos, netos, bisnetos e tetranetos do casal Baltasar e Leandra, que foram procuradores da família Ávila, originaram a família Dantas, ampliaram os domínios e ocuparam os cargos políticos e militares fundamentais na região. ${ }^{2}$

Os senhores da Casa da Torre delegavam um grande poder a seus procuradores. Proprietários de uma infinidade de terras, tiveram que manter homens de confiança em cada rincão para estabelecer a posse e administrar, ou "senhorear" como se dizia na época. Pedro Calmon afirma que o procurador representava "o dono distante, a posse armada, a propriedade". Assegura ainda que nessa associação entre os senhores e os procuradores, aqueles concediam a estes "autoridade, apoio e força" em troca de "sujeição, tributo e homenagem". Sobre a Casa da Torre diz ainda que "parecia a capital rústica de províncias solitárias que paxás do sertão, sargento-mores de índios mansos, vaqueiros-procuradores administravam por sua lei, por sua vontade, por seu capricho, dispondo da vida e dos bens dos clientes segundo as conveniências desse governo". ${ }^{3}$

Essa política de dominação deixou frutos que permaneceram, embora transmudados, largamente no tempo. Para os propósitos deste artigo, é importante tecer algumas palavras sobre as diferenças entre vaqueiros, administradores e procuradores, apreendidas na leitura de diversos documentos relativos à região de Geremoabo.

Os vaqueiros comuns lidavam diretamente com o gado, tocavam de um pasto para outro, cuidavam das bicheiras e também faziam serviços associados à criação, como conserto de cercas e limpeza dos bebedouros dos animais - as fontes e os olhos d'água. Eram personagens frequentes no final do século XIX e suas funções foram em muitas fazendas desempenhadas por escravos. Já o procurador era uma pessoa que representava o proprietário por meio de um documento que o habilitava a resolver questões burocráticas e

\footnotetext{
${ }^{1}$ Segundo o "Mapa Estatístico da Divisão Administrativa, Judiciária e Eleitoral da Província da Bahia”, de 1876, a Comarca de Geremoabo englobava o povoado de Tapera e as vilas de Geremoabo e Bom Conselho. Seus limites tocavam o Rio São Francisco no último trecho baiano ao Norte, no atual município de Paulo Afonso, avistando, portanto, as famosas cataratas de mesmo nome.

${ }^{2}$ CARVALHO JR., Álvaro P.D. O barão de Jeremoabo e a política de seu tempo - Trajetória de um líder conservador na Bahia. Secretaria da Cultura e Turismo do Estado da Bahia, 2006.

${ }^{3}$ CALMON, Pedro. História da Casa da Torre: uma dinastia de pioneiros. Salvador: Fundação Cultural da Bahia, 3.ed., 1983, pp. 123-4
} 
cartoriais. Respondia por eventuais ações na Justiça que envolvessem o fazendeiro, atuando como um administrador dos assuntos externos à fazenda propriamente dita. $\mathrm{O}$ administrador, por sua vez, cumpria a função de gerir de fato a propriedade, e por isso estava mais presente nas fazendas absenteístas, mas não apenas nelas. Era ele quem se reportava diretamente ao proprietário para dar notícia sobre as fazendas, prestar contas gerais; era quem articulava a venda de gado ou de gêneros agrícolas, organizava a contratação de empregados, vaqueiros e ajudantes, controlava e remunerava os seus serviços, além de ser o responsável pela apartação, a partilha e as ferras dos animais, momentos em geral festivos nas fazendas. ${ }^{4}$ Mas os administradores também podiam trabalhar diretamente com os animais, tocando boiadas, correndo os pastos etc. Talvez por esse motivo eles definissem a si próprios enquanto vaqueiros, como se observa nos processos criminais da Comarca de Geremoabo.

É claro que, em muitas circunstâncias, essas três funções se sobrepunham. Além do mais, a identificação por meio desses diferentes nomes tinha significados em termos de status social. Embora seja difícil captar as mudanças desses significados ao longo do tempo, parece que essa forma de administração, que supervalorizava o procurador, foi uma herança importante deixada pela Casa da Torre. Com a decadência dessa família, as novas elites que a sucederam no poder político e econômico de Geremoabo, muito menos absenteístas do que os Ávila, devem ter transferido essa onipotência para os trabalhadores mais importantes de suas fazendas, fossem eles chamados de administradores ou de vaqueiros.

Sobre o impacto da escravidão em Geremoabo, de fato não se pode afirmar que essa comarca dependia economicamente desse sistema, já que seus ciclos não estiveram diretamente associados com as flutuações no mercado de escravos ou com a própria Abolição. No entanto, por ter sido difundida a posse de escravos, esse sistema deve ter delineado as relações de dominação e as formas de resistência. ${ }^{5}$ Era nos meandros das relações pessoais que a dominação se efetivava, e não eram apenas as elites que usavam a dependência pessoal para subjugar seus trabalhadores ou se locupletavam da política, criando aí um ambiente "familiar". Essa era uma forma de exercício do poder usufruída por toda a sociedade, embora de maneiras diferenciadas, e que com Abolição deve ter sido desorganizada, rearranjada.

Associada à Abolição, havia a indefinida peregrinação de Antônio Conselheiro, que começou por volta de 1874 e só cessou em 1893, quando finalmente foi fundado o arraial de Canudos - cidadela situada às margens do mesmo rio Vaza Barris, que banhava a vila de Geremoabo. José Calasans, em seu livro Antônio Conselheiro e a escravidão, afirma a presença de ex-escravos "nas hostes do Bom Jesus Conselheiro" a partir de relatos de viajantes, notas de jornais e cartas. Em uma dessas correspondências, enviada ao barão de

\footnotetext{
${ }^{4}$ As partilhas eram também chamadas de quarteações e era o momento em que os administradores retribuíam os serviços dos vaqueiros com um de cada quatro ou cinco bois nascidos no ano. A apartação, ou "pega de bois", como era chamado na época em Geremoabo, significava reunir e diferenciar o gado solto que, em virtude da inexistência ou precariedade dos cercamentos, se misturava ao de outras fazendas.

${ }^{5}$ A análise dos inventários mostra que, no período de 1880 a 1888, 34\% dos inventários mencionam a posse de escravos, o que nos permite dimensionar a difusão do sistema escravista na Comarca de Geremoabo.
} 
Geremoabo, Antônio de Cerqueira Galo descreve um medo difundido entre as elites locais: “Lá os vultos que estão desinvolvendo (sic) a revolta. É o mesmo Conselheiro com seus sequazes d'entre estes soldados e desertores, de diversos estados e o povo 13 de maio que é a maior parte" ${ }^{6}$ As pregações de Antônio Conselheiro também davam grande ênfase à luta contra o cativeiro e à conquista de liberdade, ainda que esses conceitos fossem ampliados para a ideia de cativeiro moral e espiritual. Outrossim, numa nota de jornal, O barão de Geremoabo define o olhar das elites sobre essa perigosa associação entre conselheirismo e Abolição:

O povo em massa abandonava suas casas e afazeres para acompanhá-lo. Com a abolição do elemento servil ainda mais se fizeram sentir os efeitos da propaganda pela falta de braços livres para o trabalho. A população vivia como em delírio ou êxtase e tudo quanto não fosse útil ao inculcado enviado de Deus, facilmente não se prestava. Os cemitérios e capelinhas eram construídos com materiais carregados na cabeça ou puxados por pessoas do povo na distância. Assim foi escasseando o trabalho agrícola e é atualmente com suma dificuldades que uma ou outra propriedade funciona, embora sem a precisa regularidade. ${ }^{7}$

A observação do barão é interessante porque confirma tanto a vinculação entre o problema da Abolição e as novas questões trazidas pela pregação de Antônio Conselheiro e pela formação do Arraial de Canudos quanto a preocupação das elites em relação às mudanças nos padrões de dependência. A tônica da fala do barão é a preocupação em torno das motivações pelas quais as pessoas - ou apenas "os braços", como as elites costumam reduzir - passaram a dedicar sua força de trabalho. É preciso notar que Geremoabo era uma sociedade pouco monetarizada em que a remuneração do trabalho livre era irregular e acrescida de um bocado de pequenos favores e acordos firmados na relação pessoal entre patrões e empregados. Uma negociação cotidiana cujo êxito repousava na escolha dos laços pessoais, sejam eles oriundos de alianças sociais interessadas ou de solidariedade moral, sejam eles verticais ou horizontais, o que será melhor definido adiante.

A passagem da Monarquia para a República também não foi pacífica em Geremoabo e esteve bastante relacionada com o movimento de Antônio Conselheiro. Sendo os principais chefes políticos locais monarquistas, quando foi decretada a nova ordem, eles tiveram que se adaptar às pressas. Em 1893, as lutas políticas foram acirradas e localmente dois grupos se enfrentaram: os vianistas, partidários de Luis Vianna, então governador da Bahia, e os gonçalvistas, adeptos de José Gonçalves, antigo governador. Os processos criminais de Geremoabo estão recheados de casos de perseguição e vingança política, nos quais ocorrem agressões, soltura ilegal de presos e até incentivo e proteção aos conselheiristas com vistas a enfraquecer o governo. Embora a relação entre conselheirismo e a política local não deva ser explicada apenas como manipulação, é certo que houve essa

\footnotetext{
${ }^{6}$ CERQUeIRA GALO, 1897. Apud. CALASANS, José. Antônio Conselheiro e a escravidão. Salvador: Centro de Estudos Baianos, s/d.

${ }^{7}$ JORNAL DE NOTíCIAS. Apud. CALASANS, José. Idem.
} 
dimensão e ela fazia com que as alianças pessoais significassem um meio de proteção e um distintivo social importante para indivíduos de qualquer classe.

Portanto, a Geremoabo de finais do Oitocentos era esta: uma região sob o domínio de alguns potentados, onde a ascensão ou a simples segurança social dependiam do investimento nas relações pessoais. Também era uma comarca assolada por secas e guerras políticas, com esparsa identidade econômica, na qual seus habitantes tinham de lidar com a precariedade material, trabalhando para os grandes fazendeiros, mas preservando uma autonomia laboral que Ihes permitissem também trabalhar em suas terras, criar seus animais e cuidar de suas lavouras. E para o alerta dos poderosos, era também um lugar no qual os "mal-aventurados" estavam esperançosos com os "conselhos" sobre os novos tempos, a libertação dos homens e o "mistério da anunciação". 8

Para realizar a proposta deste artigo, será examinada sob novas lentes uma narrativa constantemente elaborada sobre as relações entre vaqueiros e fazendeiros: a de que os vaqueiros são homens "fiéis", que serviam de braço direito dos fazendeiros, que foram os principais aglutinadores de votos "no tempo da política" e eram formadores dos currais eleitorais que favoreciam os interesses de seus patrões. Essa imagem integrada em um quadro bucólico e quase imóvel das áreas rurais do Brasil, especialmente as pastoris, concorreu para uma perspectiva unidirecional da relação entre vaqueiros e fazendeiros, que identifica a intenção de dominação destes últimos com o que de fato acontecia. ${ }^{9}$

Folcloristas, memorialistas e cientistas sociais da primeira metade do século XX se empenharam juntos, embora não o soubessem, em desenhar esse quadro quieto e reiterativo do ponto de vista cultural e social das fazendas sertanejas. Nas abordagens dos autores do começo do século $\mathrm{XX}$, os atributos de fidelidade, honra, liberdade e autonomia foram definidos a priori, como típicos do vaqueiro. ${ }^{10} \mathrm{E}$ por terem sido esses atributos

\footnotetext{
${ }^{8}$ CALASANS, José. Idem.

9 Em 1888, Durval Vieira Aguiar caracteriza Geremoabo como uma "vila insípida, estacionária” e sua população como "sendo no geral muito ordeira". AGUIAR, Durval Vieira de. Descrições Práticas da Província da Bahia. [1888]. 2. ed., Rio de Janeiro; Brasília: Cátedra; MEC, 1979, p. 76.

${ }^{10}$ Ver, entre outros, MACEDO, Jozé Norberto. Fazendas de Gado no Vale do São Francisco. Documentário da Vida Rural, n. 3. Rio de Janeiro: Ministério da Agricultura - Serviço de Informação Agrícola, 1952; CARDOSO, Fernando Henrique. Capitalismo e Escravidão no Brasil Meridional. O negro na sociedade escravocrata do Rio Grande do Sul. São Paulo: Difusão Europeia do Livro, 1962; LEAL, Vítor Nunes. Coronelismo, Enxada e Voto. 2.ed., São Paulo: Alfa-Ômega, 1975; PANG, Eul-Soo. Coronelismo e Oligarquias: 1889-1943: A Bahia na Primeira República Brasileira. Rio de Janeiro: Civilização Brasileira, 1979; FREITAS, Décio. "O Capitalismo Pastoril”. In: $O$ Capitalismo Pastoril. Porto Alegre: Escola Superior de Teologia São Lourenço de Brindes, 1980; BOAVENTURA, Eurico Alves. Fidalgos e Vaqueiros. Salvador: EDUFBa, 1989; PINHO, José Ricardo Moreno. Escravos, Quilombolas ou Meeiros? Escravidão e Cultura Política no Médio São Francisco (1830-1888). Dissertação (Mestrado em História), UFBa: Salvador, 2001; CUNHA, Euclides da. Os Sertões. [1902]. São Paulo, Martin Claret, 2003; PRADO JR, Caio. Formação do Brasil Contemporâneo. Colônia. 24. a reimp. São Paulo: Editora Brasiliense LTDA, 1996; CASCUDO, Câmara. Vaqueiros e Cantadores. Folclore poético do sertão do Ceará, Paraíba, Rio Grande do Norte e Pernambuco. [1939] Rio de Janeiro: Ediouro, 2000; ABREU, Capistrano de. Capítulos de História Colonial (1500-1800). 7. ed., Belo Horizonte: Itatiaia; São Paulo: Editora da USP, 1988.
} 
naturalizados - e não problematizados enquanto valores que possuem significado social - é que este artigo pretende examiná-los sob outra ótica, reinserindo-os em sua elaboração cotidiana. Para tanto, foi escolhido um conjunto documental que mais se aproximasse dos conflitos diários e que por isso expressasse o tipo de resistência empreendida pelos vaqueiros ao poder dos grandes coronéis do gado: os processos criminais de roubo e furto de animais instaurados na comarca. Por meio desses conflitos, que punham em questão bens tão preciosos numa região de pecuária - cavalos, bois, cabras e ovelhas - e da análise das versões dadas à Justiça pelos envolvidos e pelas testemunhas, pretende-se apreender aspectos das relações de poder ali estabelecidas, da maneira como eram questionadas e em que medida os valores de fidelidade e honra da palavra eram recuperados, quiçá manipulados, nessas ocasiões.

Dos cento e sete processos instaurados em Geremoabo entre 1880 e 1900 e que sobreviveram até os dias atuais mais ou menos legíveis, vinte e cinco envolvem ou mencionam o furto de animais. Três observações sobre esses processos parecem relevantes. A primeira torna ainda mais significativo esse número de processos: doze deles fazem alusão a furtos anteriores que não foram denunciados às autoridades, o que prova que desavenças cotidianas como o furto de animais, embora fossem frequentes, raramente chegavam à Justiça, sendo mais comum que se resolvessem privadamente. Segundo, é que muito raramente havia equivalência social entre as partes em conflito. Em geral eram grandes ou médios criadores que se queixavam de lavradores, forasteiros e dos que não tinham "domicílio certo" (para quem?) nem "meios de vida conhecidos" (por quem?), o que demonstra que as suspeitas recaíam sobre aqueles que fugiam ao domínio pessoal dos proprietários em âmbitos fundamentais para a manutenção da ordem social: a moradia e o trabalho. Não há processo algum de confronto entre dois grandes fazendeiros. A terceira observação é sobre a incidência dos processos ao longo do período analisado. É marcante a concentração das denúncias de furtos entre outubro de 1888 e o ano de 1893, o que mais uma vez sugere que esse período de mudanças político-sociais e de ação dos conselheiristas e de cangaceiros instabilizou o poder das elites, tornando-as menos habilidosas para lidar com esses conflitos, ensejando desobediências mais ou menos subliminares à ordem dominante.

\section{$* * *$}

A acusação feita em 1893 pelo poderoso escrivão e fazendeiro local Porfírio da Costa Borges contra Francisco Quintino de Jesus remete a um interessante ambiente de desrespeito de autoridade. ${ }^{11}$ Segundo diversos relatos, Quintino teria recompensado com um boi um certo favor que Porfírio lhe teria feito. O problema é que em razão de "não ter sido satisfeito no quanto desejava", Francisco Quintino decidiu tomar de volta o boi e vendê-

\footnotetext{
${ }^{11}$ Processo crime de furto em que é réu Francisco Quintino de Jesus, Geremoabo, 1893, seção judiciária, APB, estante 01 , caixa 17 , documento 12 .
} 
lo à revelia de seu atual dono, muito embora testemunhas importantes como o vaqueiro da fazenda de Porfírio, Miguel Victor de Jesus, tivessem dito à polícia que era "público e notório ter o queixado sido satisfeito em tudo" e tivessem-no aconselhado a "não vender o que não Ihe pertencia".

Era "um boi gordo e bom", que decerto importava mais para Quintino - um pequeno sitiante cujo inventário em 1900 consta apenas de bens de raiz e alguns objetos pessoais - do que para Porfírio, um grande fazendeiro. ${ }^{12}$ De todo modo, a situação era delicada, já que o filho de Quintino, Antônio José dos Santos, trabalhava na fazenda de Porfírio em atividades de "pega de bois".

Também chamado de ajuntamento ou apartação, esse era um trabalho eventual que se realizava uma ou duas vezes ao ano, quando era necessário reunir o gado no curral para que, sob supervisão do administrador, se contasse e ferrasse os animais, cuidasse das bicheiras, apartasse os bezerros, fosse dado o "quarto" aos vaqueiros etc. Antônio devia trabalhar dessa forma na fazenda de Porfírio, assim como seu pai, Quintino, que declarou em seu depoimento que "vive de trabalhos" e que conhecia as testemunhas há muitos anos. Sendo as testemunhas todas trabalhadoras da fazenda de Porfírio, pode-se acreditar que Quintino prestava serviços nessa fazenda, realizando aí pelo menos alguns dos seus "trabalhos". Como não havia mão de obra farta e disponível na recôndita comarca, os trabalhadores eventuais eram, em geral, os mesmos, mas com uma outra relação de trabalho daquela estabelecida com os fixos e, porque não dizer, uma outra relação social.

Segundo Farinatti, que estudou as relações de trabalho na pecuária da região da Campanha Gaúcha, os trabalhadores eventuais eram em geral recrutados entre os agregados. ${ }^{13}$ Costumavam gozar de mais independência que os fixos por não serem fonte segura de mão de obra e, por conseguinte, nem de lealdade, obediência, e defesa dos interesses dos proprietários. Esse argumento parece fazer sentido em Geremoabo, já que foi justamente a mando de Quintino que Antônio tomou de volta o boi enquanto este trabalhava em "pega de boiadas" na fazenda de Porfírio.

Entretanto, essa não é uma diferença que deve gerar a falsa oposição entre resistência e acomodação. O "fiel" vaqueiro Miguel Victor de Jesus tinha motivos muito práticos para colocar-se ao lado de seu patrão. Primeiro porque gozava do prestígio e benesses de ser uma espécie de "vaqueiro-administrador" da fazenda Caritá, onde se deu o "furto", o que significava ter uma casa de morada próxima à sede, para si e para sua família, criar seus animais "misturado" nos pastos da fazenda, extrair leite das vacas paridas para fazer e vender requeijão, entre outros pequenos espaços, relativamente autônomos, que o fazia desfrutar das posses e bens do fazendeiro, seu patrão.

\footnotetext{
${ }^{12}$ No inventário de Francisco Quintino de Jesus não consta bem semovente algum; entretanto, no inventário de sua esposa, em 1897, constam 61 cabeças de gado vacum "de toda a sorte”, das quais Quintino herdou 28. Inventário de Francisco Quintino de Jesus, Geremoabo, 1900, seção judiciária, APB, número 04/1549/2018/02. ${ }^{13}$ FARINATTI, Luís A. E. “Nos Confins Meridionais: famílias de elite e sociedade agrária na Fronteira sul do Brasil (1825-1865)." Tese (Doutorado em História Social). Rio de Janeiro: UFRJ, 2007.
} 
E esses espaços não Ihe rendiam poucos frutos. Seu inventário não está disponível, mas ele aparece como inventariante de sua mulher que, ao falecer, deixou quase cem cabeças de animais, dentre as quais cinquenta eram de gado vacum. 0 monte-mor partilhável passava dos 3 contos, uma quantia considerável para a região. Entre os trezentos e vinte e seis inventariados, ele estava entre os vinte e quatro mais abastados entre os anos de 1880 e 1900. Ademais, Miguel Victor mantinha boa parte da família empregada como vaqueiro nas fazendas de Porfírio da Costa Borges e do barão de Geremoabo. ${ }^{14}$ Seus pais eram moradores e vaqueiros da fazenda Caritá, assim como um outro parente seu, chamado Camillo Victor de Jesus, que era "casado, vaqueiro, morador na Cacimba da Pedra deste Termo", uma das fazendas do barão. Além deste, havia ainda Domingos Victor de Jesus, que se correspondia por carta com o barão em Geremoabo na qualidade de vaqueiroadministrador. ${ }^{15} \mathrm{~A}$ julgar pelos sobrenomes, há razões para acreditar que Miguel tinha motivos estratégicos e inteligentes para manter-se ao lado de seu amo Porfírio. Ao menos era uma forma de aumentar seus créditos, dando-lhe mais poder de barganha e, afinal, garantir a segurança material da sua família.

Em Geremoabo, os vaqueiros assumiram funções que foram muito além da capatazia, ou seja, da administração integral das propriedades. Na última década do século $X I X$, se difundiu a delegação de responsabilidades e cargos policiais aos vaqueiros que reforçavam, assim, uma hierarquia superior diante de outros trabalhadores e afirmavam na prática uma espécie de "coronelismo ao rés do chão".

Um distintivo importante desse trabalhador era sua vestimenta, que consistia em um uniforme de couro, hoje já muito difundido como o traje típico do vaqueiro. "As vestes são uma armadura", dizia um ilustre observador da região, Euclides da Cunha: "O seu aspecto recorda, vagamente, à primeira vista, o de guerreiro antigo exausto da refrega." 16 Era uma roupa que deixava o vaqueiro preparado para a lide com o gado bravio na vegetação fechada e espinhenta que caracterizava os pastos do Sertão. Mas era também um aspecto que o destacava visualmente na sociedade e por vezes permitia intersecção entre a função de vistoriar o gado, na qual ocupava a maior parte do tempo, e a de vigilância social.

Em pelo menos dois processos há referência explícita a vaqueiros que são reconhecidos pela função de inspetores de quarteirão e guardas de tropa. ${ }^{17}$ Nessas funções, eram requisitados para resolver conflitos, perseguir bandidos e até dar voz de prisão na falta de um delegado. Nos demais processos que se referem aos furtos de animais, os vaqueiros são testemunhas valiosas para averiguar a verdadeira propriedade de muitos animais,

\footnotetext{
${ }^{14} \mathrm{O}$ escrivão e o barão eram muito amigos, sendo Porfírio seu procurador mais importante. A fazenda Caritá, onde nasceu o barão, e tempos depois foi ocupada por Porfírio, foi onde aconteceu o furto do boi.

${ }^{15}$ Há um conjunto de correspondências do barão que é bastante sugestivo das relações de trabalho em Geremoabo, e que foi em parte por mim analisada na dissertação. MEDRADO, Joana. Op. cit.

${ }^{16}$ CUNHA, Euclides, Op. cit., p. 119

${ }^{17}$ Processo crime de apelação em que é réu Tertuliano de Sant'Anna, Geremoabo, 1889, seção judiciária, APB, estante 04, caixa, 139, documento 02; Processo crime de homicídio em que é réu Manoel Rodrigues da Silva (e outros), Geremoabo, 1898, seção judiciária, APB, estante 28, caixa 983, documento 21.
} 
certamente porque eram os responsáveis pela apartação e partilha nas fazendas e, portanto, conhecedores dos ferros e marcas dos fazendeiros.

Esse acúmulo de responsabilidades que os vaqueiros iam assumindo, com o passar dos anos de trabalho numa fazenda, foi fator central para o aumento do seu prestígio social e poder de influência. As mudanças nas formas de dominação que estavam sendo processadas no último decênio do século XIX significaram alterações nas estratégias de obter segurança e ascender socialmente. $O$ fim da escravidão desfez a hierarquia oficial/civil entre os trabalhadores de uma fazenda e criou a necessidade entre os trabalhadores livres e especializados de reafirmar valores e virtudes que os diferenciassem da mão de obra comum. A fidelidade, a honra da palavra, a coragem, a dignidade e a confiabilidade eram alguns desses valores, e os vaqueiros foram os principais trabalhadores que os mantiveram e os reforçaram. Os fazendeiros, logicamente, tentaram se apropriar desse discurso a seu favor, e os memorialistas, folcloristas e alguns sociólogos repercutiram apenas essa versão dos valores.

A fidelidade entre fazendeiros e vaqueiros é reforçada nesse viés por Câmara Cascudo $^{18}$, que agrupa esse tema na seção "Contos de exemplo". ${ }^{19}$ Aí ele apresenta duas histórias: "Quirino, Vaqueiro do Rei" e "Boi Leição", variantes narrativas da história de um vaqueiro que é testado na sua capacidade de não mentir. Um fidalgo aposta com o rei (ou na história do "Boi Leição", dois fazendeiros apostam entre si) a veracidade da palavra de um vaqueiro, criando uma situação na qual este, tendo que atender aos desejos gastronômicos de sua companheira grávida, deve matar o boi mais importante da fazenda de seu "amo" para lhe tirar o fígado.

Muito embora o vaqueiro tenha, afinal, decidido matar o boi numa verdadeira carnificina, colocando o capricho de sua mulher acima da vontade do fazendeiro, essa não é a questão enfatizada na história. Ao contrário, há um desvio narrativo para destacar o momento final da aposta quando o vaqueiro confessa para o fazendeiro ter matado seu boi preferido acompanhado de uma espécie de "moral da história" na qual são elevadas a honra e a fidelidade do vaqueiro que, acima de tudo, "não mente".

Outro exemplo é a análise de Jozé Norberto Macedo, estudioso das fazendas de gado do São Francisco, que diz:

\begin{abstract}
Animal marcado ou ferrado tem seu dono e é por isso respeitado ainda que fuja e permaneça durante anos seguidos em terras estranhas. O sentido de respeito à propriedade alheia, altamente desenvolvido entre os criadores e vaqueiros, é uma nota de caráter daquela gente, explicando-se assim como podem animais de diferentes donos viver a vida livre das terras abertas, sem controle, apenas de longe em longe visitados pelo vaqueiro. ${ }^{20}$
\end{abstract}

\footnotetext{
${ }^{18}$ CASCUDO, Câmara. Contos tradicionais do Brasil. [1946]. 20. ed., Rio de Janeiro: Ediouro, 2003.

${ }^{19}$ CASCUDO, 2003.

${ }^{20}$ MACEDO, 1952, p. 35
} 
Uma avaliação que não ajuda a explicar casos reais analisados na Comarca de Geremoabo, que devia partilhar alguns valores da região contígua do São Francisco. Ao contrário, todos os casos de furto analisados tratam de animais cujo possessório era de conhecimento geral. Além disso, raros são os processos em que os réus negam o furto, e é significativo que em nenhum deles sejam usadas justificativas como a seca e a fome que se alastravam nesse período, não obstante tais motivações terem o poder de sensibilizar juízes e coronéis. Outro aspecto relevante é que, na maioria dos casos, os ladrões não eram forasteiros, o tipo mais temido entre os proprietários. Ao contrário, eram bastante relacionados com a comunidade na qual realizaram seus furtos.

Diferentemente dos conflitos em torno da posse de terras no século XIX, que em geral visavam à ampliação de domínios sobre terras devolutas, ou ainda os conflitos em torno da propriedade de gado xucros, ou selvagens, na província de Rio Grande de São Pedro, no mesmo período, os conflitos que observamos em Geremoabo se davam regularmente em torno de animais cujo possessório era reconhecido por todos. Inclusive pelos supostos ladrões, já que os animais eram ferrados ou assinalados nas orelhas - as duas formas básicas de marcar a posse sobre um animal. Portanto, o que ocorriam nessas paragens eram cenas de homens disputando entre si bens que nenhuma situação de guerra ou de brecha na legislação justificava a existência de polêmica. Eram homens burlando símbolos de pertencimento largamente estabelecidos.

O principal ritual de posse de animais em Geremoabo era o momento de ferra de gado. Essa era uma atividade que reunia todos os trabalhadores fixos de uma fazenda e mais outros contratados apenas para aquele serviço. Nesses momentos, em Geremoabo, chamados de "pegas de bois" ou "pegas de boiadas", os animais eram apartados (daí o termo igualmente usado "apartação") e marcados com um ferro quente nos quartos traseiros, imprimindo no couro do animal um símbolo criado pelo dono. Mas não era apenas essa marca que traziam as reses. Em virtude de compras e vendas, trocas, doações, ou mesmo pagamentos aos vaqueiros em animais, elas eram ferradas duas ou mais vezes e também assinaladas nas orelhas com cortes específicos.

O fato de serem festivas essas ocasiões tornava ainda mais público os possessórios. Portanto, era difícil confundir um animal. Além dos ferros, outros sinais identificavam-no e definiam sua propriedade, tornando-se o couro um importante signo de pertencimento, além de ser também uma peça de muito valor no mercado. ${ }^{21}$ Mesmo correndo riscos, vendiam-na para auferir mais lucro, como fez Alexandre, que furtou uma ovelha "e depois não temeu nem se arreceiou de publicamente vender o couro dela". Era justamente no momento de venda do couro que muitos ladrões eram pegos ou vistos pelas testemunhas que usavam essa informação como prova principal do furto. Há pelo menos dois casos em

\footnotetext{
${ }^{21} \mathrm{Em}$ algumas regiões, o couro chegava a representar $95 \%$ do valor total do animal. Por isso não se pode considerar apenas como simbólico o ato de devolver o couro ao "verdadeiro" dono.
} 
que os ladrões se propuseram a entregar de volta o couro do animal furtado para remediar a situação, devolvendo, simbolicamente, a propriedade ao dono. ${ }^{22}$

Além de serem excelentes janelas para observar uma sociedade, os processos criminais, especificamente os de furto, ajudam a tecer o argumento de que ao discutir a posse de um animal estava-se questionando a propriedade mais valiosa (simbólica e econômica) dos fazendeiros e coronéis, e com isso seu próprio poder de mando.

Nesse sentido, um interessante argumento que aparece nos processos como explicação para o roubo de animais era o de invasão de roças. Nas zonas de pecuária, em geral, eram os plantadores que tinham a obrigação de construir os travessões, espécie de cerca de madeira que livrava a roça do gado solto. ${ }^{23}$ Mas nem sempre isso ocorria em Geremoabo, ou seja, nem sempre os lavradores submetiam-se aos grandes criadores e a invasão das lavouras por criações era um argumento fortíssimo usado para justificar casos de agressões ao dono do gado e furtos seguidos ou não de morte dos animais. Há, entre eles, dois episódios nos quais o furto foi seguido de matança do animal e retalhamento da carne, o que pode sugerir mais uma atitude simbólica de contestação do poder local.

Em um deles, os acusados eram conhecidos egressos de Canudos, Joaquim, Benjamim e Manoel Batista do Nascimento, e teriam roubado um boi pertencente a Pedro Nolasco de Carvalho, assim como matado e dividido a carne com os "companheiros". ${ }^{24}$ Serviu de testemunha o vaqueiro de outra fazenda, que, por precaução, se dirigiu à casa dos réus "a fim de saber se era alguma das reses de que ele era vaqueiro", ali se deparando com o couro do boi espichado na porta da casa, o que demonstra que os réus não temiam incriminações.

Nos depoimentos das testemunhas, o réu Joaquim interferia sempre fazendo um adendo, informando que de fato haviam matado a rês, "pelo fato de achar-se a mesma dentro de suas roças a estragarem as plantações; mas fizeram [isso] no sentido de pagarem ao dono o prejuízo causado". Portanto, o furto e a matança foram uma forma de compensar a roça estragada - já que perderam para o boi os frutos da roça, então comeriam o próprio boi - sendo também uma espécie de represália ao fazendeiro Pedro. Joaquim até mesmo disse a diversas testemunhas que de fato haviam aproveitado a carne, mas que "se o dono procurasse o couro entregaria, se não procurasse ficaria com ele". Sendo o couro um importante signo de propriedade, como foi dito acima, essa proposta de Joaquim parece ser uma tentativa de mostrar publicamente que não se estava questionando a propriedade do boi e nem tentando auferir lucro, e sim dando uma lição no dono dele.

\footnotetext{
${ }^{22}$ Processo crime de roubo em que é réu João Francisco das Chagas, Cícero Dantas, 1890, seção judiciária, APB, estante 08, caixa 255, documento 25; Processo crime de roubo em que é réu Joaquim Baptista do Nascimento (e outros), Cícero Dantas, 1900, seção judiciária, APB, estante 08, caixa 253, documento 03.

${ }^{23}$ Não foi possível reproduzir aqui a análise dos inventários da comarca que mostra a identificação entre os detentores de maior monte-mor com os detentores da maior quantidade de animais, o que comprova que essa era uma região onde os fazendeiros e coronéis eram, sobretudo, pecuaristas - uma informação que pode parecer óbvia, mas que é importante à pesquisa para não reproduzir estereótipos.

${ }^{24}$ Processo crime de roubo em que é réu Joaquim Baptista do Nascimento (e outros), Cícero Dantas, 1900, seção judiciária, APB, estante 08 , caixa 253 , documento 03.
} 
O outro caso foi ainda mais dramático. Nele, o fazendeiro Manuel de Castro Teixeira fez uma denúncia contra o fazendeiro Pedro Galdino, João Roberto (vaqueiro de Pedro) e Baldoino Teixeira, os quais, segundo ele, denunciante, teriam lhe roubado "um touro malhado de preto e branco, casteado de gadomar e raça taurina". ${ }^{25}$ A julgar pela descrição minuciosa de raça se percebe que este não era qualquer boi, e sim, no mínimo, um touro reprodutor da fazenda, aliás, segundo o próprio fazendeiro "peça importantíssima de alto valor e estima". Esse boi teria recebido onze machadadas de Baldoíno, mas não morrera. Ainda cambaleante, precisou ser sangrado. Finda a matança, o boi "de alto valor e estima" foi literalmente esquartejado, ficando um quarto para cada um dos valentes acusados, o couro para Pedro e o fato (intestinos) para a "jagunçada" que estava trabalhando.

Essa cena de horror para os olhos modernos foi entendida com naturalidade pelos contemporâneos. O próprio dono do boi, antes de denunciar o furto para o poder público, tentou, durante dois anos, negociar com Pedro Galdino um irônico pagamento em parcelas para compensar o prejuízo que teve com seu touro de raça, furtado e esquartejado. Mas houve discórdia entre os três acusados sobre a legitimidade do pagamento e o acordo não deu certo. O primeiro a se negar a pagar a indenização e, portanto, a recusar um acordo privado entre os ladrões e o dono do boi, foi Baldoino, que de pronto respondera a Pedro que "não tinha medo de processo pelo que já tinha sido processado por três vezes e nunca fez caso de processo", num tom de audácia que lembra Francisco Quintino de Jesus - que havia tomado de volta a novilha peitando o escrivão Porfírio há algumas linhas. À semelhança do que ocorrera entre Porfírio e Quintino, e que fizera o primeiro retirar a acusação contra o segundo, alguma coisa o fazendeiro Manuel tinha feito de errado e isso poderia comprometê-lo no julgamento. Por isso, talvez, tivesse demorado dois anos até decidir entrar com um processo. O fato, sabidamente omitido da sua representação à Justiça, foi relatado à polícia por uma de suas testemunhas, Major Clementino Pereira da Gama:

\footnotetext{
Respondeu que sabe por ouvir dizer que em dias do mês de dezembro de 1898 que o touro entrando nos pastos de capim pertencentes ao Pedro Galdino este pegara o dito touro e amarrou em um pau com intenção de fazer o dito touro levar ali uns três dias, e ao depois soltar; nesta ocasião chegando Baldoino convidara a eles para matarem o touro, mas não consentindo a mulher de João que isso fizessem soltaram o dito touro, e Baldoino seguiu ao encalço com João e Pedro e adiante pegaram o touro e mataram, sendo divididas entre eles na forma em que foram ditos.
}

Portanto, o boi tinha invadido os pastos de Pedro e essa foi a razão pela qual este considerou justa uma retaliação: ela seria iniciada com o ato de deixar o boi amarrado em um pau por três dias. No entanto, por terem considerado insuficiente essa punição, eles resolveram matar o boi. Quanto ao vaqueiro de Pedro, José Roberto, parece ter tentado

\footnotetext{
${ }^{25}$ Gadomá é uma corruptela de gademar, denominação dada ao boi mestiço de zebu com caracu. Processo crime de furto em que é réu Pedro Galdino (e outros), Cícero Dantas, 1900, seção judiciária, APB, estante 19, caixa 653, documento 23 .
} 
esquivar-se da culpa, opondo-se à realização da matança e proferindo enérgica e enigmática frase: "O diabo está no olho daquele pau". Ele e sua mulher, segundo testemunhas, teriam aconselhado os outros a não maltratar o touro de Manuel Teixeira, embora ele estivesse pastando em campos indevidos. Justamente num pasto de Pedro, com quem o denunciante já tivera rixa por causa de uma outra "vaca gadomá de grande vulto e valor", cuja carne também fora retalhada para o consumo da casa.

Em seu livro Encruzilhadas da Liberdade, Walter Fraga analisa os tumultuados dias que se seguiram à Abolição no Recôncavo Baiano e dedica um capítulo à análise de um caso que envolveu a matança de bois de um engenho. ${ }^{26} \mathrm{O}$ estopim que justificou a instauração do processo criminal foi o espancamento do administrador desse engenho pelos recentes libertos pela lei de 13 de maio. 0 espancamento se deu quando o administrador perguntou ao feitor o motivo pelo qual os moradores tinham ferido e matado alguns bois do engenho. Nem este, nem os ex-escravos toleraram a voz de mando do administrador e espancaram-no com paus, pedras e instrumentos de trabalho.

Os depoimentos dos envolvidos mostram que o motivo da agressão aos bois foi a invasão das roças dos trabalhadores do engenho pelo gado dos proprietários. Essa era uma questão antiga que simbolizava a opressão do senhor sobre os espaços de autonomia longa e arduamente conquistados pelos escravos e libertos. Ao matarem os bois que invadiam corriqueiramente suas roças, os trabalhadores matavam simbolicamente seus antigos senhores. Prova disso é que deram os nomes dos donos dos engenhos aos bois que estavam sendo retalhados. Fraga interpreta esse acontecimento como uma tentativa de consolidar enquanto direito o acesso e a produção na terra por meio das roças de subsistência, o que foi durante muito tempo entendido como uma concessão senhorial. Ainda que os escravos tivessem conquistado esse direito, ele ainda não era completo, visto que uma eventual invasão de bois nas suas roças seria normalmente tolerada e não revidada de maneira tão brutal como aconteceu nesse episódio. Portanto, o pós-Abolição foi um momento chave na inserção de novos significados nas relações sociais e de trabalho, e de ampliação do caráter meramente civil da liberdade conquistada.

No caso de Geremoabo, não parece ter havido um corte tão radical no pósAbolição. Existe uma concentração de furtos nos cinco anos que se seguem a 1888, mas não há nenhuma referência objetiva a esse acontecimento nos processos e nem mesmo a exescravos como réus. A Comarca de Bom Conselho, cuja vila se emancipa no início da década de 1890 , segue o mesmo padrão, tendo os furtos se concentrado nos anos de 1888 e $1897 .{ }^{27}$ Por isso a hipótese deste trabalho é que a ação dos conselheiristas e a Guerra em Canudos foram eventos de maior relevância na reorganização dos poderes locais do que o evento da Abolição, cujos efeitos foram mais diluídos.

\footnotetext{
${ }^{26}$ FRAGA FILHO, Walter. Encruzilhadas da liberdade: histórias de escravos e libertos na Bahia (1870-1910). Campinas/SP: Editora da Unicamp, 2006, pp. 165-212.

${ }^{27}$ A primeira expedição ocorre no início de novembro de 1896 e os últimos defensores de Canudos morrem no dia 5 de outubro de 1897.
} 
Talvez por isso recaíssem fortes suspeitas sobre aqueles que retornaram de Canudos. Alguns processos da Comarca de Bom Conselho fazem referência a réus que "desde quando voltaram de Canudos só tem se empregado em furtos". É claro que em grande medida essas suspeitas refletiam um "medo construído" especialmente pelas disputas entre facções políticas, mas também pela Igreja Católica e pelo Exército, como avalia Consuelo Novais Sampaio. ${ }^{28}$ Essa atmosfera de medo teria sido fundamental para as elites que tentavam reaver o domínio político há pouco perdido e acreditavam que uma desordem social "ameaçadora", que justificasse a intervenção do governo federal, era a estratégia mais viável para se ter êxito.

Entretanto, é necessário cautela para não considerar a questão de Canudos como apenas um teatro das manipulações políticas locais e nacionais. Além da guerra física que culminou na destruição total do arraial, houve também uma guerra moral que não findou em 1897 e colocou em discussão os motivos da obediência - afinal, algumas centenas de pessoas decidiram não mais sujeitar-se aos seus ex-senhores ou patrões, ou ainda aos fazendeiros de quem arrendavam terras ou eram agregados, e optaram por obedecer ao Bom Jesus Conselheiro e trabalhar para o Arraial.

Portanto, as suspeitas que recaíram, por exemplo, sobre os irmãos Joaquim, Benjamim e Manoel Batista do Nascimento e outros companheiros, referidos anteriormente, tinham um lado bastante concreto. Inclusive porque já fazia três anos de finda a guerra quando foram processados e as testemunhas afirmaram que eles, "desde que vieram dos Canudos tem vivido do furto e costumam dividir entre si produto de seus furtos". Resultado ou não de uma consciência social formada durante a experiência na cidadela revoltosa, esses réus furtaram e mataram diversos animais com o argumento de que eles haviam invadido suas plantações e, enquanto retalhavam o boi, responderam aos presentes que "enquanto houvesse gado no mato e mandiocas nas roças não passariam fome" ${ }^{29}$ Muito mais do que famintos desesperados e irracionalizados, esses réus tinham concepções morais sobre a propriedade privada e sobre o limite do domínio dos fazendeiros.

A referência constante das testemunhas de acusação de que os egressos de Canudos eram "useiros e vezeiros em furtar" pode ser um indício de que depois da guerra restou mais do que fome, necessidade física e um "grande medo", como afirma Sampaio. Talvez a experiência nessa cidadela tenha significado a possibilidade de se estabelecer uma relação menos temerosa entre os roceiros e pequenos criadores com os fazendeiros. Uma postura, talvez, menos prepotente por parte dos fazendeiros e mais audaciosa por parte dos trabalhadores.

Concomitante aos furtos de apenas um animal, havia também aqueles que subtraíam mais de cinquenta deles das fazendas. Esse tipo de furto geralmente ocorria em

\footnotetext{
${ }^{28}$ SAMPAIO, Consuelo Novais. Canudos: Cartas para o barão. São Paulo: Imprensa Oficial do Estado de São Paulo, 1999, pp. 31-60.

${ }^{29}$ Processo crime de roubo em que é réu Joaquim Baptista do Nascimento (e outros), Cícero Dantas, 1900, seção judiciária, APB, estante 08, caixa 253, documento 03; Processo crime de furto em que é réu Manoel Maria do Nascimento, Cícero Dantas, 1899, seção judiciária, APB, estante 05, caixa 177, documento 17.
} 
pequenos lotes semanais, o que sugere serem as vítimas grandes proprietários que precisavam contar com a administração indireta de suas posses.

Quando José da Costa Silva Passos, criador e proprietário, decidiu pôr fim à série de furtos que ocorria em seus rebanhos ovelhum e cabrum em duas de suas fazendas, quatro distintos fazendeiros vieram acudi-lo testemunhando a seu favor e legitimando sua queixa. Ele denunciava que, ao longo de nove meses, cinquenta cabeças de animais haviam sido subtraídas de seu domínio e, segundo os depoimentos das testemunhas, os acusados tinham levado também gados, criações e lavouras de outros fazendeiros. Apenas nos idos de 1891 é que o fazendeiro resolveu dar queixa dos acusados que "de um ano para cá têm furtado duplamente". Nos processos, verifica-se que os animais roubados eram descarnados e vendidos "regularmente" para os açougues locais. ${ }^{30}$

A impressão que se tem ao examinar esse processo é que o criador era relapso ou seu vaqueiro conivente com os furtos, afinal, o sumiço de cinquenta cabeças não é nada desprezível, ainda que tivessem ocorrido "em lotes semanais". Considerando que a vítima não residia em uma das fazendas onde ocorreram os furtos, as duas possibilidades são válidas. A inexistência de cercas e a administração indireta poderiam explicar tanto a impossibilidade de "tomar conta de tudo" quanto certa conivência costumeira dos vaqueiros com os furtos.

Examinando alguns aspectos da estrutura narrativa desse processo criminal, observam-se algumas diferenças em relação aos demais, o que pode ajudar a esclarecer esse ponto. Das sete testemunhas que depuseram a favor de José da Costa, quatro eram proprietários de terras e animais que fizeram um discurso fervoroso contra o costume do roubo que se instaurou "de um ano para cá" em Geremoabo e desde que os acusados "obtiveram uso de varão". ${ }^{31} \mathrm{Na}$ realidade, eles não disseram nada sobre os furtos propriamente ditos, ou seja, apesar de deporem como testemunhas, eles não o foram de fato, e nesse caso os depoimentos tiveram apenas o sentido de endossar a acusação dizendo que "o conteúdo da petição que Ihe fora lida é verdadeira". Os três depoimentos restantes são de lavradores de lugares aparentemente não relacionados com as fazendas Barroquinha ou Itapicuru d'Água, onde aconteceram os furtos.

Mas onde estava o vaqueiro dessas fazendas que não depôs, como era normal nesse tipo de processo? Apesar de não ter sido encontrado o inventário de José da Costa,

\footnotetext{
${ }^{30}$ Processo crime de furto em que é réu Manoel Gomes de Souza (e outros), Geremoabo, 1892, seção judiciária, APB, estante 09, caixa 301, documento 12; Processo crime de furto em que é réu Baldoino Teixeira de Castro, Cícero Dantas, 1899, seção judiciária, APB, estante 05, caixa 177, documento 15.

${ }^{31}$ Esta é uma expressão usada em dois processos, ambos de 1892, e pode se referir à maioridade civil, pensando varão como sinônimo de homem adulto. Mas como a expressão era usada para se referir a um grupo de pessoas, pode-se aventar a possibilidade de que, no contexto do paternalismo sertanejo, o tornar-se adulto, ou varão, pudesse ser uma expressão para designar os recém-libertados pela lei abolicionista de 1888 . Na falta de outros indícios que comprovem essa hipótese, admite-se também a expressão como indicativa do uso recente de algum instrumento, sendo possível, nesse caso, que seja uma corruptela da palavra "vara de ferrão", vara comprida com uma ponta de ferro correntemente usada pelos vaqueiros para cutucar e vaquejar o gado - agradeço a Walter Fraga Filho por essa observação. De qualquer maneira, ainda permanece a dúvida sobre o que poderia mesmo significar esse termo.
} 
infere-se, a partir de aspectos desse processo e do inventário de seu sogro - um fazendeiro bem aquinhoado - que ele era um grande criador que devia contar com um vaqueiroadministrador, pois dificilmente cuidaria sozinho de suas propriedades. Portanto, a ausência do vaqueiro, de algum empregado seu ou mesmo de algum agregado nos depoimentos é forte indício de que o fazendeiro ignorava o cultivo de laços de solidariedade mais estreitos com seus dependentes, expondo-se assim à insubordinação e à deslealdade.

É importante salientar que o cultivo de laços de solidariedade verticais que evoluíssem para alianças sociais mais sólidas não era tarefa simples nas zonas de pecuária. Farinatti observa que não era apenas a propriedade de terras e bens que colocava as elites numa condição natural de vantagem na dominação social. Elas deveriam explorar aspectos como o gerenciamento competente das suas atividades econômicas, o fornecimento de crédito para os seus trabalhadores e agregados, a manutenção de boas e eficientes relações sociais com seus pares (que permitissem, por exemplo, receber e repassar favores). Além disso, valia a pena apostar no apadrinhamento, incentivar o comprometimento eleitoral e os recrutamentos militares, sendo este último talvez um aspecto mais próprio da região de fronteira estudada pelo autor, a Campanha Gaúcha. ${ }^{32}$

Afora esse último aspecto, que deve ser relativizado para a região de Geremoabo, não obstante a guerra em Canudos tivesse dividido a sociedade durante quase toda a década de 1890, os outros aspectos eram bastante valorizados pelos trabalhadores dessa comarca. E a constituição de dependentes era vital para uma elite de proprietários cujos olhos não alcançavam os limites de suas terras, muito menos o rumo de seus animais. Mas o fazendeiro José da Costa parece não ter sido feliz na realização desse modelo tão em voga no período, ou não ter acreditado nele como o mais eficaz.

Essa situação recoloca a questão da fidelidade incondicional dos vaqueiros para com seus patrões, reiterada pela literatura sociológica ou folclórica. A possível conivência do vaqueiro com os furtos nas fazendas Barroquinha e Itapicuru d'Água, em decorrência da possível incompetência de José da Costa para cultivar laços de solidariedade verticais, mostra que a existência de um acordo social entre fazendeiros e vaqueiros não era uma regra, e sim uma fórmula que costumava dar certo. Era uma norma de conduta e um tipo de associação útil para ambas as partes - de um lado fidelidade, prontidão e proteção e, do outro, benesses materiais, algum prestígio social e também proteção. Mas Geremoabo tinha uma estrutura social muito mais complexa e estava passando por um momento especial de incerteza política e de desolação social, o que tornava vital a criação de novas alianças sociais ou alguns ajustes nas existentes. Estudando um povoado piemontês no século XVII, Giovanni Levi reflete com muita propriedade sobre a questão da criação e adaptação de normas de comportamento num contexto de imprevisibilidade:

Na medida em que foi a própria incerteza a dar lugar à criação de normas que tornassem previsível o comportamento de cada indivíduo para todos os outros, foi

\footnotetext{
${ }^{32}$ FARINATTI, Op. cit., p. 377.
} 
a mesma dificuldade de previsão que fez com que estas normas fossem elásticas e ambíguas de forma a consentirem uma contínua adaptação. ${ }^{33}$

Vários outros processos se destacam pela quantidade de animais furtados, mas não será possível analisá-los aqui, em virtude da brevidade do artigo. Em um deles são duas as vítimas: José Lourenço de Carvalho, do qual foram furtados duas criações; e Gaudêncio Rebello de Alcântara, de cujo rebanho de ovelhas "tem desaparecido sessenta cabeças às quatro ou cinco semanalmente". Em um outro processo, o padrão se repete: são quarenta animais furtados, e vaqueiros e moradores da fazenda depõem confirmando o furto. ${ }^{34}$

Nesse clima de desconfiança cotidiana que permanecia às vezes durante anos, uma pergunta se faz inevitável. Haveria alguém ou algum grupo viabilizando os furtos? De maneira quase automática, o olhar recai sobre os vaqueiros que eram os administradores de fato das propriedades, especialmente nas absenteístas. Eles eram exímios conhecedores das fazendas, vistoriavam os pastos e sabiam a quantidade exata de animais, as vacas paridas, as melhores criações, entre outros detalhes. Eram eles os responsáveis pelas partilhas de animais e por definir os novos possessórios. Em grande medida, os vaqueiros tinham também interesse pessoal no bom desempenho dessas tarefas, porque era costume que mantivessem os seus próprios animais nos pastos de seus patrões. Ou seja, tratava-se de um grau de conhecimento e ingerência nos assuntos da fazenda tão agudo que não parece absurdo supor que eles facilitavam, ou mesmo se locupletavam dos furtos e posteriores revendas.

Sobre o caso ocorrido em Bom Conselho, de furto e matança do touro "gadomá" do fazendeiro Manuel de Castro por Pedro Galdino, João Roberto e Baldoino Teixeira, a vítima fez uma declaração muito interessante. Em sua representação à Justiça, Manuel, que não residia na fazenda onde aconteceram os furtos, disse que além de furtar, Pedro Galdino teria o hábito de negociar com os vaqueiros das fazendas a ajuda para realizar seus furtos:

É tal a audácia do dito Pedro Galdino que seduz vaqueiros a furtarem animais da Fazenda e a ele venderem, como aconteceu a meu ex-vaqueiro Francisco Lima, a quem propôs que ocultamente vendesse-lhe um burro; igual proposta fez a Anízio Maranduba.

Esses fatos não foram investigados pela polícia, o que resulta na falta de elementos para concluir a partir desse processo que os vaqueiros de Manuel de fato intermediavam e lucravam com os furtos. A representação à Justiça, que normalmente vinha logo no início do processo, continha muitas informações que não precisavam ser comprovadas para a polícia e apenas serviam para reiterar a pertinência da denúncia, não gerando novas acusações. Entretanto, o grau de detalhamento dessa afirmação, contendo, por exemplo, o nome dos

\footnotetext{
${ }^{33}$ LEVI, Giovanni. A Herança Imaterial. Trajetória de um exorcista no Piemonte do século XVII. Rio de Janeiro: Civilização Brasileira, 2000, p. 105.

${ }^{34}$ Processo crime de furto em que é ré Ângela Gomes de Souza, Geremoabo, 1892, seção judiciária, APB, estante 09, caixa 301, documento 13; Processo crime de danos em que é réu Estanislão Bispo dos Anjos (e outros), Geremoabo, 1892, seção judiciária, APB, estante 09, caixa 301, documento 10.
} 
vaqueiros supostamente envolvidos, confere credibilidade ao texto. Além disso, no meio do depoimento de uma das testemunhas, infere-se que o vaqueiro de Manuel na época do processo era outro, a propósito seu xará, Manoel Dias, o que indica que possivelmente ele despediu os dois citados acima que cederam à "sedução" de Pedro.

Por razões ignoradas, o vaqueiro Manuel Dias não consta no rol de testemunhas apresentado pela acusação. Não obstante tenha participado da busca ao touro roubado e tivesse, por isso, muito mais a dizer do que muitas testemunhas que apenas reiteraram "o que tem ouvido dizer" e "o que é voz pública". Ou ele não se dispôs a servir de testemunha ou, o que parece mais provável, o fazendeiro, desiludido com os vaqueiros anteriores, não teve confiança em chamá-lo para depor.

Márcia Motta reflete sobre o significado da escolha das testemunhas quando analisa os processos cíveis de embargo de Paraíba do Sul entre 1834 e $1858 .{ }^{35}$ Ela acredita que esse era um momento chave na definição dos tipos sociais que mereciam mais ou menos crédito. No seu estudo, verificou uma tendência a escolher homens brancos casados e mais velhos, o que estava de acordo com os preceitos gerais das Ordenações Filipinas sobre a importância da qualificação das testemunhas. É claro que essa não era uma receita infalível para se obter sucesso na arena judicial, mas esses eram critérios de respeitabilidade regularmente seguidos. Associado a isso, Motta observa ainda que

mais importante era o fato de que a escolha das testemunhas implicava a capacidade de articulação de uma pessoa com seus pares e/ou subordinados, de convencê-los a se apresentar perante o juiz, confirmando os seus argumentos. [...] Em outras tantas, apresentava o esforço de outros sujeitos sociais para constituírem laços de solidariedades na sua luta contra um ou mais fazendeiros. ${ }^{36}$

Nos processos de furto de Geremoabo, vê-se que o rol de testemunhas apresentado à Justiça pelo fazendeiro lesado indicava, em regra, sua capacidade de articulação, bem como seus aliados sociais. Em grande parte dos processos analisados, os fazendeiros apresentaram seus vaqueiros como principais testemunhas. Mas como ficou patente nos casos de José da Costa Silva Passos e de Manuel Teixeira, alguns proprietários não tinham a mesma conduta, provavelmente por desinteresse ou inabilidade na construção de laços verticais de solidariedade. Apresentando ou não seu testemunho à Justiça, o vaqueiro era peça central para dirimir as dúvidas sobre furtos e sua "palavra de honra" era muito considerada.

A grande maioria dos vaqueiros citados nos processos de furtos de animais em Geremoabo foi testemunha dos crimes. Dos vinte e quatro vaqueiros que tiveram seus nomes citados nos processos, vinte e dois foram apenas testemunhas dos atos. Um dado que induz a crer que os vaqueiros não se envolviam em furtos, pois seu papel principal nos processos de Geremoabo era o de testemunhas. Seriam, inclusive, delatores ativos já que

\footnotetext{
${ }^{35}$ MOTTA, Márcia Maria Menendes. Nas Fronteiras do poder: conflito e direito a terra no Brasil do século XIX. Rio de Janeiro: Arquivo Nacional do Estado do Rio de Janeiro; Vício de Leitura, 1998.

${ }^{36}$ Idem, p. 73.
} 
seus testemunhos foram sempre a favor do lado prejudicado pelo furto, ou seja, dos fazendeiros. Contudo, é preciso observar algumas limitações da fonte aqui usada. A identidade ocupacional declarada nos processos é resultado de algumas escolhas sociais e estava relacionada com a própria construção da autonomia. Alguns indícios levam a crer que a identificação como lavrador (muito mais frequente) era sinônimo de maior autonomia enquanto a de vaqueiro evidenciava subordinação e dependência. Entretanto, essas identidades não eram fixas, podendo um mesmo indivíduo trabalhar como vaqueiro de outrem e ser também lavrador de suas próprias roças ou comerciante e vice-versa. Assim, no momento em que cometiam um crime e tinham que responder perante à Justiça sobre suas identidades, poderiam mobilizar aquela que julgavam mais conveniente, e esse fato desautoriza o pesquisador a considerar a declaração que vai registrada no processo como a "verdadeira" ocupação dos indivíduos.

De todo modo, definir o vaqueiro como defensor dos interesses do fazendeiro ou como aquele que tirava proveito da situação de proximidade com o patrão para obter vantagens não é tarefa simples para os historiadores, nem para o fazendeiro em busca de um vaqueiro de confiança que o substituísse na ausência. As duas situações ocorreram em Geremoabo, como na maioria das zonas de pecuária que tiveram origem em grandes latifúndios absenteístas. Essa ambiguidade, por seu lado, permite intepretar com mais discernimento um campo normalmente cheio de observações impressionistas que alude à força e à credibilidade social dos vaqueiros e administradores, bem como ao seu afamado conhecimento da fazenda, dos animais, da terra e da gente do lugar, em muitos casos superior ao conhecimento que o próprio fazendeiro tinha. ${ }^{37}$

Por isso, apesar das limitações dos processos criminais como fonte, é significativo o fato de que a grande maioria dos vaqueiros citados tenha servido de testemunha (e não de réus ou vítimas), indicando que esse era o seu papel prevalecente. É significativo também que, apesar das exceções que comprovam tanto a diversidade quanto a própria "regra" da sociedade, os vaqueiros administradores de Geremoabo mantinham alta credibilidade social e os fazendeiros, em geral, apostavam nessa aliança vertical. Entretanto, tratava-se de uma aposta: se o laço fosse estabelecido, significava compromissos de ambos os lados, e o fazendeiro tinha que cumprir as funções que lhe cabiam.

Certa feita, o ex governador da Bahia José Gonçalves escreveu mais uma de suas
muitas cartas para o barão de Geremoabo. Exasperado com os ladrões de gado que
"exercitam impunemente sua profissão" pedia algumas providências do barão nas
suas áreas de influência, dizendo assim:
Não sei o que faço para coibir o furto nesses lugares; parece que há propósito de
me prejudicar, seja como for tenho (...) mandado os administradores,
acompanhados de vaqueiros, arrebanhando o que encontram, declarando por toda
a parte que ninguém, nem eles próprios, têm ordem de vender gado nosso; mas
tudo tem sido baldado: moradores e ladrões somados, todos ali me não pouparam.

\footnotetext{
${ }^{37}$ MACEDO, Joze Norberto, Op. cit; RIBEIRO, Áureo Magalhães. As Estradas da vida: Histórias da terra, da fazenda e do trabalho no Mucuri e Jequitinhonha, Minas Gerais. Tese (Doutorado em História), Campinas: IFCH-Unicamp, 1997.
} 
Sendo uma infelicidade que atualmente me persegue. Viram que, em tempo, por insensatez, abandonei o que era meu, e não admitem, hoje, que eu recupere o que anda disperso. Peço que escrevas aos teus vaqueiros daqueles lados ordenandoIhes que não consintam que quem quer que seja venda ou pegue gado nosso, e o não entregue senão a administradores e vaqueiros meus, montados a cavalos com os meus ferros, ou marcas. ${ }^{38}$

Em muitas outras cartas são comentadas situações desse tipo, mas em geral apenas num tom queixumeiro. Na de José Gonçalves há uma rica observação sobre diversos aspectos dos furtos, alguns dos quais difusamente mencionados nos processos criminais.

Essa é uma visão íntima das elites do gado que remete a um ambiente de preocupações em torno de retaliações política ou social, desconfianças em relação aos empregados e das fragilidades do exercício e dos símbolos de poder. José Gonçalves acreditava que o furto de gado nas suas propriedades, que já somavam mais de quarenta animais, estava relacionado ao fato de ter abandonado o que era seu. Essa é uma das faces mais concretas do absenteísmo e que parece ser mais comum nesse período e região: proprietários de muitas terras, que apesar de morarem em uma fazenda (e não na capital), não iam com a frequência necessária visitar as outras propriedades e nem mantinham vaqueiros residindo nelas. Nesses casos, o gado solto ficava sem controle e era peça visada pelos ladrões. A tentativa do fazendeiro de "recuperar o que anda disperso" era em vão, pois, provavelmente, a essa altura, moradores e ladrões estavam convencidos de que as terras estavam abandonadas. Essa é uma versão que dificilmente seria contada à Justiça pelas vítimas que instauravam um processo, mas que aqui, numa carta entre amigos, desabafa-se.

Um outro aspecto que essa carta nos traz é a cautela em relação a vaqueiros e administradores. Embora estes fossem os responsáveis pelo gado do fazendeiro, "nem eles próprios" tinham ordens para vendê-lo. Nesse caso, José Gonçalves parece querer prevenirse contra a situação que sucedeu ao fazendeiro Manuel Teixeira, na qual os vaqueiros, por terem acesso fácil aos animais da fazenda, poderiam roubá-los e vendê-los para outrem, repassando também a culpa pelo furto. Ele frisa para quem os animais roubados poderiam ser devolvidos: aos "administradores e vaqueiros meus, montados a cavalos com os meus ferros, ou marcas", o que leva a crer que era comum ladrões fingirem ser vaqueiros para vender e receber gado dos fazendeiros sem desconfiança da comunidade.

Descortina-se, assim, uma sociedade complexa cujas nuances e tensões aparecem tanto nos processos criminais quanto nos desabafos de uma correspondência entre amigos. Ao findar este artigo, está claro que não foi possível definir regras de conduta e comportamentos padrões nas relações de trabalho entre vaqueiros e fazendeiros. Ao focar nos conflitos em torno do furto de animais, observa-se que o estabelecimento de confiança e fidelidade entre indivíduos de diferentes classes sociais era um terreno movediço, especialmente em se tratando de uma comunidade cuja necessidade de sobrevivência era

\footnotetext{
${ }^{38}$ Carta enviada por José Gonçalves para o barão de Geremoabo, 17 de março de 1900, correspondência passiva, fundo Barão de Jeremoabo, FCM, documento 1258.
} 
mais importante do que a de ascensão social. Talvez, à semelhança do que ocorria no povoado rural de Santena no século XVII, e em tantos outros povoados rurais, os habitantes de Geremoabo estavam prioritariamente em busca de segurança. Como observa Levi, "a melhoria econômica era um objetivo subordinado à ampliação e confirmação das relações sociais sobre as quais se fundavam as necessidades de subsistência". ${ }^{39} \mathrm{E}$ foi nesse processo de tentativa de ampliar e confirmar as relações sociais que fazendeiros, vaqueiros e trabalhadores autônomos definiam e redefiniam seus laços de solidariedade, mobilizavam suas identidades sociais, ponderavam suas diferentes concepções de poder, trabalho e sociedade e definiam a aparência de seus conflitos cotidianos: ora assumidos tête à tête, ora sutil e sabidamente contornados.

Recebido em 31/10/2012

Aceito para publicação em 03/02/2013

${ }^{39}$ LEVI, Giovanni, Op. cit., p. 105. 